\title{
THE CONCEPT OF ECOLOGICAL LAW AND ITS PLACE IN LEGAL SYSTEM
}

\section{Kostytsky V.}

\section{INTRODUCTION}

Peculiarities of modern globalized world stipulate the necessity in reframing our ideas about law and state and their role and place in development of civil society. The development of legal system leads to severance of new legal branches and institutes. Therefore, we will logically begin our research of ecological law place and role in legal system from analysis of modern understanding law and legal system, law structure peculiarities and other theoretic and methodological problems. Finding out the question of the essence of a particular branch of law and its place in the system of law requires the study of the socio-legal bases of its origin, history of origin, principles and possible ways of development.

\section{Sociological and legal basis for the emergence of environmental law}

State legal system determines not only the form of government, political (legal) regime but also characterizes the features of its modern development, as the modern state cannot be isolated from the global world. Legal system is a system of legal norms, or legal norms and legal relations, or construction of law as a normative formation and correlation of law-making and enforcement ${ }^{1}$.

In the common social understanding law means certain possibilities of social life subjects determined by the level of social development ${ }^{2}$. Thus, law turns from limitation of law into phenomenon where system of person's limitations and his/her duties corresponds with state's duties and person's possibilities.

1 Костицький В. В. Екологія перехідного періоду: право, держава, економіка (економіко-правовий механізм охорони навколишнього природного середовища в Україні) / В. В. Костицький ; Інститут законодавчих передбачень і правової експертизи. К. : УСП МСБ "Еusmeu”, 2003. - 772 с. - (Серія "Екологічна бібліотечка" ; № 5) (Бібліотечка журналу "Малий та середній бізнес"). - С. 189-203. Kostytsky V.V. Ecology of Transition: Law, State, Economy (Economic and Legal Mechanism of Environmental Protection in Ukraine) / VV Kostytskyi; Institute for Legislative Predictions and Legal Expertise. - K.: USSB SME Eusmeu, 2003. - 772 p. - (Series "Ecological Library"; № 5) (Library of the magazine "Small and Medium Business"). - P. 189-203.

${ }^{2}$ Рабінович П.М. Права людини та їх юридичне забезпечення (основи загальної теорії права і держави). - К., 1992. - С. 7. Rabinovich PM Human rights and their legal support (foundations of the general theory of law and state). - K., 1992. - P. 7. 
During the last decades in Ukraine the law was traditionally examined as a mirror of public relations reflected only attained level of development and deprived of creative force as a secondary (built-on) element of reality, an addition to economic relations which serves the tools of economy. Peculiarity of the previous approach to understanding law was determined by the Soviet subjective normativizm ${ }^{3}$, i.e. denial of the private in law, absolutization of public law, stipulated by ideological vision of law set by the state.

This, in our opinion, generated legal nihilizm, underestimation of law, ignoring it in enormous scales of socio-economic development of a giant state.

"First of all, law is direct presence of existence...", wrote G. Hegel in his work "Philosophy of Law", in other words the phenomenon and essence without which it is difficult to imagine the modern society. A fashion on G. Hegel did not pass but his definition of law as a necessary element of existence was understood somewhat simplified.

Law is a social phenomenon ${ }^{5}$, an achievement of spiritual culture and art that is why law cannot be deprived of creative basis with the help of which new socio-economic relations develop. Ukrainian experience, the Constitution of Ukraine (1996), the project of which was created with the author's input as a model for development of the state, forming the legal system, civil society and a new free man, is the best argument in favour of such a statement.

Law as an organized matter of high spirit shows us such aspects which we did not notice before. Let us recall that an ancient saying interprets law as an art of good and justice. Obviously, the Constitution of Ukraine developing this position in the Article 3 has ascertained that a person, their freedom determine

${ }^{3}$ Костицький В. Приватне право і підприємництво в Україні. Вступ до збірника наукових праць "Приватне право і підприємництво”. - К., 1999. - С. 5-11. Костицький В.В. Методологічні проблеми кодифікації екологічного законодавства / В. Костицький // Малий і середній бізнес (Право, Держава, Економіка). - 2011. - № 3-4. - С. 3-6; Костицький В.В. Міжнародно-правовий етичний імператив як основа теоретико-методологічного забезпечення розвитку екологічного права / В. Костицький // Право України. - 2011. № 2. - C. 20-33. Kostytsky V. Private Law and Entrepreneurship in Ukraine. Introduction to the collection of scientific works "Private Law and Entrepreneurship". - K., 1999. - P. 5-11; Kostytsky V.V. Methodological problems of codification of environmental legislation / V. Kostitsky // Small and medium-sized business (Law, State, Economics). - 2011. - № 3-4. P. 3-6; Kostytsky V.V., International legal ethical imperative as the basis of theoretical and methodological support for the development of environmental law / V. Kostytskyi // Law of Ukraine. - 2011. - № 2. - P. 20-33.

${ }^{4}$ Гегель Г.В.Ф. Философия права. - М.: “Мысль”, 1990. - С. 99. Hegel GVF Philosophy of Law. - M. : "Thought", 1990. - P. 99.

${ }^{5}$ Алексеев С.С. Право. Азбука. Теория. Философия. Опыт комплексного исследования. - М.: Статут, 1999. Alekseev S.S. Right. Alphabet. Theory. Philosophy. Experience in complex research. - M. : Charter, 1999. 
the substance and directions of country's activity, turning law from the gifted possibility into the system of conventional rules of equal subjects - the person and the state.

Freedom and necessity are two real criteria, two real keys to understanding law as an integral phenomenon which combines public and private life of the society. Freedom per se is alive when like a bird it can have two wings, one of which is private life of a person, based on the right to one's own identity and private property, and the second is the right to participating in public life, obviously, foremost - the right to vote. And then the necessity is understood as a duty of an individual to take into account public and private interests while realizing one's own interests.

Contrary to legal system as a multitude of all legal phenomena the legal system includes fields of law and institutes of law. There arises a logical question whether it is possible to distinguish branches in the legal system which belongs to private law, and to designate fields of law which are public law. On the level of division of law into branches it is yet possible to talk about it: civil law undoubtedly makes the basis of private law. Natural law, as Ulpian said, also belongs to private law. There are rights and freedoms of a person in natural law which are inalienably proper to it as a biosocial creature and they cannot be given by the state, and only owing to their acknowledgement by the state must be recorded in the constitution as a public agreement of citizens inter se, the civil society and the state. Here the level of publicity of natural law corresponds to the level of publicity of civil law.

Therefore, constitutional law, administrative law, criminal law are branches of public law. However, while considering law as a system which includes structural units, there appears a certain convention in the division of law into public and private. Even in civil law as a field of private law there are public and legal norms, in particular, those which are concerned with legal regulation of intellectual property. And in such fields of public law as constitutional law and land law we can find norms which regulate relations of land leasing. Here the subjects of tenancy contracts are: local self-government bodies and state executive authority, physical or legal entities. The conclusion of tenancy contract happens after the procedure of taking a corresponding decision by the local self-government body or state executive authority, and that is the matter of public law. A decision-making procedure about the conclusion of tenancy contract by a legal entity is a matter of private law.

One of displays of integrity of law apart from its division into public and private and their unity is formation of a complex field of law - "ecological law" that combines in itself forms of public and private law, includes both norms of ecological law and norms of other fields of law. 
Let us try to single out features of this statement:

1. Person's innate right to the environment suitable for life and safe for health and living lies in the basis of ecological law. This right correlates with the corresponding duty of the state which is envisaged presently in the Article 16 of the Constitution of Ukraine: the state is incumbent on providing ecological safety and maintenance of ecological balance on the territory of Ukraine, overcoming consequences of the Chornobyl disaster - the disaster of the planetary scale, genetic conservation of Ukrainian people. This norm of public law found its development in the "Basic Bill of Private Law" - the Civil Code of Ukraine which came into effect in January $1^{\text {st }}, 2004$. In the Article 293 of the Civil Code of Ukraine entitled right to the environment safe for life and health, in particular, is marked: "A physical entity has a right to the environment safe for life and health, right to reliable information on environmental conditions, on the quality of food and everyday life objects, and also a right to its collection and distribution".

2. The activity of physical and legal entities which results in damaging, spoiling and pollution of environment is illegal. Everybody has a right to demand stopping this activity. The activity of a physical and legal entity which harms the environment can be stopped through a court's decision.

3. A physical entity has a right to safe consumer products (food and everyday life objects).

4. A physical entity has a right to proper, safe, healthy conditions of work, living, studying etc. Article 293 of the Civil Code of Ukraine corresponds not only to the Article 16 but also Article 50 of the Constitution of Ukraine which also establishes the right of a person to ecological safety but is narrower in its content.

We can mention once again that a combination of norms of public and private law as demonstration of unity of law and its division into branches but, foremost, of its integrity, can be especially vividly seen in ecological law. Integrity of law is the law of its existence. In our opinion, economic and legal mechanism of environmental protection is one of displays of the integrity of law ${ }^{6}$. The task and optimal result of realization of economic and legal

6 Костицький В. В. Екологія перехідного періоду: право, держава, економіка (економіко-правовий механізм охорони навколишнього природного середовища в Україні) / В. В. Костицький ; Інститут законодавчих передбачень і правової експертизи. К.: УСП МСБ "Eusmeu”, 2003. - 772 с. - (Серія “Екологічна бібліотечка" ; № 5) (Бібліотечка журналу "Малий та середній бізнес"). - C. 189-203. Kostytsky V.V. Ecology of Transition: Law, State, Economy (Economic and Legal Mechanism of Environmental Protection in Ukraine) / VV Kostytskyi; Institute for Legislative Predictions and Legal Expertise. - K.: USSB SME Eusmeu, 2003. - 772 p. - (Series "Ecological Library"; № 5) (Library of the magazine "Small and Medium Business"). - P. 189-203. 
mechanism of protection of natural environment lies in achieving harmonious relations in the "society and nature" system which, for example, is possible to express through the concept of ecological legal order and ecological safety. Professor V. Petrov, in particular, defined ecological legal order as a "system of legal norms and legal relations which determine the mode of rational exploitation of natural resources, environmental protection and ecological safety of the society"7.

In any case the result of legal regulation of ecological relations must convey a certain state of public relations in the sphere of cooperation of society and nature, and in this case the quality of environment is favourable for a person and separate natural components, and the quality and the amount of natural resources cater for the economy of present and future generations of people ${ }^{8}$.

Such efficiency of public relations is possible only under conditions of ecological stability which means the ability of an ecosystem to resist abiotic and biotic factors of the environment, including anthropogenic influences ${ }^{9}$.

Law is practically the only, both effective and resultative, universal instrument of solution to these problems. Because of the combination of principles, functions and tasks, legal norms and rules envisaged in the acts of legislation, the institute of ecological law is called to pawn fundamental principles of forming parameters of behavioural characteristics of subjects of ecological relations through:

- formation of new ecological and legal worldview;

- creation of the effective system of environmental education;

- formation of modern ecological legislation;

- creation of an effective control system in the sphere of exploitation of natural resources and environmental protection;

- development of effective ecological policy and its successive realization;

7 Петров В.В. Закон Российской Федерации об ответственности за экологические преступления (Проект) // Вестник Московского ун-та. - Сер.11. - Право. - 1993. - № 4. C. 54. Поняттю екологічного правопорядку присвячена монографія: Petrov V.V. Law of the Russian Federation on responsibility for environmental crimes (Project) // Bulletin of the Moscow Univ. - Aug.11. - Right. - 1993. - № 4. - P. 54. The concept of environmental law is devoted to the monograph:

${ }^{8}$ Екологічна Конституція Землі. Методологічні засади / [В.В. Костицький та ін. за ред. акад. НАН України, д-ра екон. наук, проф. Ю.Ю. Туниці]. - Львів : РВВ НЛТУ України, 2011. - C. 370-381. Ecological Constitution of the Earth. Methodological basis / [V.V. Kostytsky et al. in a row. Acad. NAS of Ukraine, Doctor of Economics. of sciences, prof. Tunisia]. - Lviv: RVV NLTU of Ukraine, 2011. - P. 370-381.

${ }^{9}$ Протасов В.Ф., Молчанов А.В. Словарь экологических терминов и понятий. - М., 1997. - C. 101. Protasov V.F., Molchanov A.V. Dictionary of environmental terms and concepts. - M., 1997. - P. 101. 
- formulation of legal principles of people's participation in controlling and monitoring in the sphere of exploitation of natural resources and environmental protection.

Optimization of behavioural characteristics of participants of ecological relations on the basis of providing ecological vector in the system of their internal motivations are directed at balancing forms of cooperation of the society and nature. In scientific literature one distinguishes the following forms of cooperation of society and nature:

- economic form - nature consumption, its use for one's own needs;

- biological form - satisfaction of person's physical, biological and other physiological needs on principles of existence in the environment;

- ecological form - protection, environment recreation;

- spiritual form - cultural and aesthetic perception of nature.

The aim of balancing consists in creation of such a model of exploitation of natural resources which would provide the normal process of evolution of the society on principles of steady development. Proper creation of legal principles of realization of the given aim is a key problem for the institute of ecological law that gives ground for considering it from positions of a universal instrument of problem-solving concerning cooperation of the society and nature.

The law of every state as a system which includes such structural units as branches of law is in permanent dynamics. Besides, traditional fields of law such as constitutional, civil, criminal, administrative, financial, labour, civil procedure, procedural criminal law etc., other fields of law are forming and becoming firmly established. Today distinction of ecological law as a branch of law is universally accepted; people continue to discuss further development of economic law as an independent field.

The branch of law unites a relatively independent set of legal norms which regulate certain spheres of public relations. Large branches of law can unite both institutes of law and large groupings - sub-branches of law, i.e. complexes of legal norms which regulate public relations of one kind (banking, budget law included in the branch of financial law). The institute of law is a set of interconnected norms which are isolated inside one or a few branches of law that regulate a small group of public relations of one kind or sides of public relations ${ }^{10}$. Institutes of law in this context may refer to branches or sub-branches.

\footnotetext{
${ }^{10}$ Костицький В.В. Розвиток системи права: проблеми формування нових галузей / В. Костицький // Малий і середній бізнес. - 2008. - № 3-4. - С. 3-14. До питання про розвиток системи права та критерії його поділу на галузі (на прикладі екологічного й повітряного права). - Про українське право: Часопис кафедри теорії та історії держави і права Київ. нац. ун-ту імені Тараса Шевченка / За ред. проф. І. Безклубого. - К.: Грамота,
} 
And, finally, the smallest structural constituent in the legal system is a legal norm, i.e. a certain rule of behaviour, set or sanctioned and provided by the state. The legal norm can be compared to a molecule of the substance. A molecule is the smallest constituent of the substance which carries properties of this substance. A molecule of water is water, and two atoms of hydrogen or an atom of oxygen have different properties in comparison to water. The legal norm is the smallest part of law which has properties and specificity of law. Therefore, equalling a legal norm to a simple rule of behaviour somewhat simplifies the nature of law.

Such peculiarities of law can be most vividly seen in ecological law which includes legal norms directed at environmental protection.

Thus, ecological law is a complex branch of law that regulates legal relations in the sphere of environmental protection, rational use of natural resources and providing ecological safety, i.e. relations related to protection and use of environment on the whole and natural resources of environment with the aim of providing permanent balanced development in interests of present and future generations of people.

In Ukraine the main characteristics of development of ecological law consists in expansion of its action, itemization of many legal requirements. A short process of its development in independent Ukraine underlines the fact that expansion of the sphere of ecological law is an objective process. The tendency of expansion of the sphere of ecological law in Ukraine is far from being exhausted even today. In particular, it is confirmed by the fact that the problem of substantial updating and perfection of ecological law acquires considerable importance. The point is that the intensity of formation of this branch of law has resulted in adoption of many hasty and imperfect legal norms which were often corrected in recent years. Weak financial and economic validity of many statements of ecological law has revealed itself. All this has required earlier and requires now permanent adjustment of a considerable number of existing normative materials, it often generates unsystematic and frequent changes in the mechanism of legal regulation of ecological relations, puts forward the need of codification of ecological law and adoption of the Ecological Code of Ukraine.

2009. - Чис. IV. - С. 128-143 (384 с.). Kostytsky V.V. Development of the Law System: Problems of Forming New Industries / V. Kostytsky // Small and Medium Business. - 2008. № 3-4. - P. 3-14; The question of the development of the system of law and the criteria for its division into industry (for example, environmental and air law). - About Ukrainian Law: Journal of the Department of Theory and History of State and Law, Kyiv. nat. Univ. of Taras Shevchenko / Ed. prof. I. Blessed. - K. : Certificate, 2009. - Numbers. IV. - Pp. 128-143 (384 pp.). 


\section{History of the emergence of Environmental Law in Ukraine}

By examining and analyzing peculiarities of legal support of protection and rational use of the environment and its natural resources in Ukraine we turn to the features of generation and development of ecological law system. It is a separate complex branch of law within limits of the national legal system and it develops with its own specificity. Let us consider the features of development of the legal mechanism of environmental protection in modern Ukraine, not claiming that our analysis will be full and exhaustible.

First of all, we should mention that ecological law as a branch of law of independent Ukraine has developed earlier and develops now on the basis of the science of ecological law, foremost, theoretical works of such Ukrainian scholars as: V. Andreytsev, H. Balyuk, A. Bobkova, A. Hetman, S. Kravchenko, N. Malysheva, V. Muntyan, Z. Pavlovych, O. Pohribnyy, B. Rozovskyy, V. Popov, V. Semchuk, Yu. Shemshuchenko, M. Shulha, Z. Yanchuk, V. Yanchuk, and also scholarly-theoretical ideas of the best representatives of the post-soviet school of ecological law - O. Kolbasov, V. Petrov (Moskow), M. Storozhev (Belarus, Minsk), S. Baysalov (Kazakhstan, Alma-Ata), V. Yakovlyev (Moldova), etc.

We should emphasize that after the first research paper of these scientists. In Ukraine these were articles and later monographs by V. Muntyan, $\mathrm{N}$. Tytova which were dedicated to problems of collective farm and land law and legal protection of nature.

The number of papers which have not only scientific but also cognitive value has increased lately. They include summarizing courses on Ukrainian ecological law, published as collective and individual works (to the latter belong course books prepared by V. Andreytsev ${ }^{11}$ and M. Malyshko, also by Yaroslav the Wise National Law Academy with the help of A. Hetman, V. Popov and M. Shulha).

The concept "ecological law" in legislative practice has become universally known but at the same time it remains debatable in science. Thus, a Russian researcher, professor O. Kolbasov, whose contribution to development of ecological law theory is one of the most valuable, thought that in the legal system land, water, mountain, and forest law are absolutely equal inter se and with other branches but differ in the degree of development which is determined by certain historical conditions ${ }^{12}$. Stressing the fact that

11 Андрейцев В.І. Екологічне право: Курс лекцій в схемах. Загальна частина. - К.: "Вентурі", 1996. Andreytsev VI Environmental Law: Lecture Course in Schemes. The common part. - K. : Venturi, 1996.

${ }^{12}$ Колбасов О.С. Экология: политика - право. Правовая охрана природы в СССР. - М.: "Наука", 1976. - C. 146. Kolbasov O.S. Ecology: politics - law. Legal protection of nature in the USSR. - M. : "Science”, 1976. - P. 146. 
environmental protection as a complex universal problem is solved by facilities of all branches of law, O. Kolbasov suggested using terms "environmental protection (ecological) law" (which is maybe even efficient) for designation of certain directions of theoretical researches or educational disciplines, not associating the essence of these terms with the Soviet law system. In his opinion, yet it was impossible to prove the existence of the branch of environmental protection law at that time (in the 1970-ies). It was possible only to humbly speak about the tendency of formation of such a branch of law. The integrated branch of law the origin of which it is possible to expect, as a researcher wrote, should be named not "natural resources law", but "ecological law"13.

Ukrainian scholar Yu. Shemshuchenko claims that the essence of the corresponding branch of law is more precisely represented in the term "environmental law" than in the term "ecological law" ". Environmental law, in his opinion, has its own subject of legal regulation which is characteristic only of this branch. It is represented by numerous public relations in the sphere of cooperation of the society (the man) and environment that differ in certain content, but display organic and stable unity, i.e. ecological relations. In Yu. Shemshuchenko's opinion, there is commonness of the aim at the achievement of which public relations are directed by corresponding norms; they are the following: to provide harmonious cooperation of man and nature, to create environmental conditions favourable for person's life ${ }^{15}$. Complex character of legal regulation, commonness of aims and specificity of content prove to be, as the researcher thinks, an integral property of the legal community which appears in the form of an unusual and complex branch of environmental law. Its inner structure is composed by separate norms, institutes, and also branches of land, water, forest, atmospheric and faunistic law.

Another researcher V. Petrov consistently adhered to the term "ecological law", alluding to disagreement of participants of the scholarly discussion in 1987 with the "pro-western transcription" of the name of this discipline environmental law ${ }^{16}$. He pointed to a rather complex classification of norms of ecological law, to which he refers as behavioural, which regulate people's

${ }^{13}$ Колбасов О.С. Экология: политика - право. Правовая охрана природы в СССР. - М.: "Наука", 1976. - С. 155-156. Kolbasov OS Ecology: politics - law. Legal protection of nature in the USSR. - M. : "Science", 1976. - P. 146.

${ }^{14}$ Шемшученко Ю.С. Правовые проблемы экологии. - К.: Наук. думка, 1989. - С. 68. Shemshuchenko YS Legal problems of ecology. - K. : Sciences. Thought, 1989 - P. 68.

${ }^{15}$ Шемшученко Ю.С. Правовые проблемы экологии. - К.: Наук. думка, 1989. - С. 70. Shemshuchenko YS Legal problems of ecology. - K. : Sciences. Thought, 1989 - P. 68.

${ }^{16}$ Петров В.В. Экологическое право России. Учебник для вузов. - М.: БЕК, 1995. C. 5. Petrov V.V. Environmental Law of Russia. Textbook for universities. - M. : BEC, 1995. - P. 5. 
relations in the sphere of environmental protection and use; he divided them into three groups, and it is possible to agree with them:

- branch norms (protection and use of separate natural objects - land, bowels, waters, etc.);

- complex norms (protection and use of natural complexes, environment in general);

- ecologizational (norms of other branches of law that represent requirements of environmental protection).

According to ecological prescriptions V. Petrov divided ecological and legal norms into norms-principles, norms-priorities, and norms-rules:

- norms-principles contain principles of environmental protection;

- norms-priorities set legal advantages in the use and protection of certain objects. They, in turn, can belong to three levels: branch, inter-branch and general ecological levels;

- norms-rules contain ecological imperatives concerning a certain sphere of ecological relations. According to their content they are divided into preventive, prohibitive, recommencing, punitive, encouraging, authorizing, allowing, and obligatory ${ }^{17}$.

Origin and development of ecological law in Ukraine has resulted from objective requirements of the community development, it is a logical result of evolution of relations between society and nature within the framework of that type of community development which during decades has been formed in our state. Views on the content of this branch of law have evolved on the basis of corresponding public needs, practice of creation of the state.

At the same time development of ecological law in Ukraine was slowed by both factors of ideological character and substantial drawbacks of the law science which turned out to be absolutely unready to adequately comprehend needs of practice which developed quickly, by erroneous solutions to many ecologically meaningful questions, by nihilistic tendencies that denied even the possibility of existence of ecological law or substantially underestimated it.

In this respect the most important thing we should pay attention to is the speed of formation and intensity of development of Ukrainian ecological law, especially after 1986. First steps of the Soviet republic and later a separate state were expressed in the legal form, absorbing both achievements and mistakes of early years of Ukrainian independence. The first years of the Ukrainian state became the period of stormy legislative and generally lawmaking activity, formation and development of a number of new branches of law among which ecological law occupies one of the key positions.

${ }^{17}$ Петров В.В. Экологическое право России. Учебник для вузов. - М.: БЕК, 1995. C. 62-65. Petrov V.V. Environmental Law of Russia. Textbook for universities. - M. : BEC, 1995. - P. 62-65. 
Analogous examples are practically unknown to history when the basics of ecological law were created during several years. Practice has confirmed that legal norms are effective and reliable means of realization of social needs in ascertaining the optimal form of mutual relations between society and nature.

Today in Ukraine the conception of theoretical principles of development of separate branches of law has not been worked out yet. This also concerns ecological law.

The author of this textbook (V. Kostytsky) back in 1992 presented his own version of this conception and named it the conception of the "ecological tree". It contains a close list of necessary legal acts in the sphere of environmental protection; it represents cooperation and general principles of their preparation and development of the system of ecological law ${ }^{18}$.

According to this conception the "ecological tree" (see Fig. 1) is based on the Law of Ukraine "On Protection of Natural Environment" dated June $25^{\text {th }}$, 1991 in which constitutional statements in relation to environmental protection are reflected ${ }^{19}$.

The Constitution stipulates principles of Ukrainian ecological policy and duty of the state as for providing ecological safety. The Main Law of Ukraine sets guarantees of human rights to safe environment for life and health and lays a duty of compensation of the harm caused to the environment on all nature users (articles 50, 66). Every citizen has a right to use natural objects belonging to people's property (land, its bowels, atmospheric air and other natural resources which are within the limits of the territory of Ukraine, natural resources of its continental shelf, exceptional (marine) economic zone).

${ }^{18}$ Костицький В. Проблеми розвитку екологічного права України / Зб. тез: Екологічний менеджмент в Україні: порівняльний аналіз українського та західноєвропейського підходів. - 21-31 травня 1991р. - Женева. - 1991. - С. 161; Костицький В.В. Екологічне право України: деякі проблеми теорії та кодифікації // Право України. - 1998. - № 1. C. 67-72. Kostytsky V. Problems of development of environmental law of Ukraine / Coll. of theses: Environmental Management in Ukraine: A Comparative Analysis of Ukrainian and Western European Approaches. - May 21-31, 1991 - Geneva. - 1991 - P.161; Kostytsky V.V. Ecological law of Ukraine: some problems of theory and codification // Law of Ukraine. 1998. - № 1. - P. 67-72.

19 Костицький В. В. Екологія перехідного періоду: право, держава, економіка (економіко-правовий механізм охорони навколишнього природного середовища в Україні) / В. В. Костицький ; Інститут законодавчих передбачень і правової експертизи. К. : УСП МСБ "Еusmeu", 2003. - 772 с. - (Серія "Екологічна бібліотечка"; № 5) (Бібліотечка журналу "Малий та середній бізнес"). - C. 189-203. Kostytsky V.V. Ecology of Transition: Law, State, Economy (Economic and Legal Mechanism of Environmental Protection in Ukraine) / VV Kostytskyi; Institute for Legislative Predictions and Legal Expertise. - K.: USSB SME Eusmeu, 2003. - 772 p. - (Series "Ecological Library"; № 5) (Library of the magazine "Small and Medium Business"). - P. 189-203. 


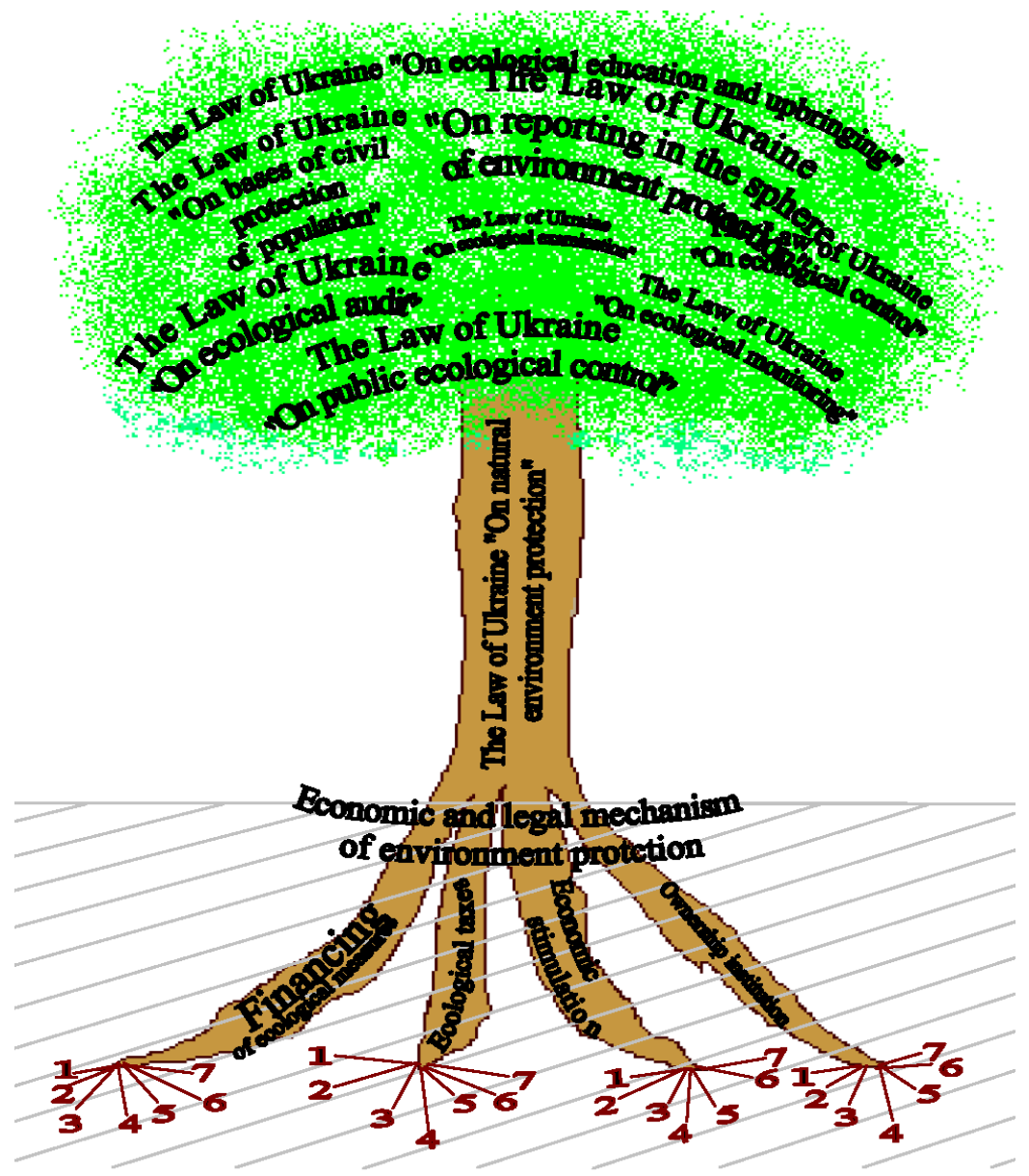

1 - Land law; 2 - Forest law; 3 - Water law; 4 - Bowels law; 5 - Atmospher protection law; 6 - Floristic law; 7 - Faunistic law;

Fig. 1. The "Ecological Tree"

The Law of Ukraine "On Protection of Natural Environment" determines general principles of environmental protection and is the basis of ecological law system. To innovations of this law one should include its structure, content and tasks. The most important here is the creation of legal terms for anti-pollution campaigns not against consequences, but reasons for 
anthropogenic and man-caused influence on the environment, beginning from technological processes. The system of ecological norms and standards is meant here. Thus, the law contains a list of ecological norms of maximum possible types of air pollution by stationary and movable sources; pollutants come into atmosphere from exploitation of technological and other equipment, buildings and objects; the law also describes norms of use of atmospheric air for industrial needs.

The "root system" of the "ecological tree" is presented by the acts of natural resources law - the Land, Forest, Water Codes of Ukraine, the Code of Ukraine on Bowels, laws on protection and rational use of flora and fauna, nature reserve fund, on air protection, and also by-laws to support the abovementioned laws. Input of economic and legal mechanism of exploitation of natural resources, which will be mentioned further, is one of the factors of viability of the "root system" of the "ecological tree". Legislative control of exploitation of natural resources, natural resources law is a basis which "holds" the "ecological tree" and simultaneously due to tax and financial law (constituents of economic and legal mechanism) "feeds" it, supports the effectiveness of all the system of ecological law.

The "crown" of the "ecological tree" is formed by legislative and normative acts of preventive character which like "leaves of a tree" play a "filter" role, preventing negative influence of human activity on the environment. It is, in particular, laws on ecological examination, status of zones of ecological emergencies, control in the sphere of environmental protection, statements about public ecological inspection, ways of spreading information on environmental protection, ecological monitoring and other legal acts, i.e. legislation which makes the basis of ecological safety without which the "ecological tree" will "dry up", and economic and legal mechanism of environmental protection will not work (see Fig. $2^{20}$ ).

Today it is possible to claim that the "ecological tree" has already "grown" in Ukrainian legislation; in our state the national system of ecological law was formed as a complex branch of law which includes legal norms and legal relations that arise in the process of cooperation of society and nature.

20 Костицький В. В. Екологія перехідного періоду: право, держава, економіка (економіко-правовий механізм охорони навколишнього природного середовища в Україні) / В. В. Костицький ; Інститут законодавчих передбачень і правової експертизи. К. : УСП МСБ "Еusmeu”, 2003. - 772 с. - (Серія "Екологічна бібліотечка" ; № 5) (Бібліотечка журналу "Малий та середній бізнес"). - C. 189-203. Kostytsky V.V. Ecology of Transition: Law, State, Economy (Economic and Legal Mechanism of Environmental Protection in Ukraine) / VV Kostytskyi; Institute for Legislative Predictions and Legal Expertise. - K.: USSB SME Eusmeu, 2003. - 772 p. - (Series "Ecological Library"; № 5) (Library of the magazine "Small and Medium Business"). - P. 189-203. 


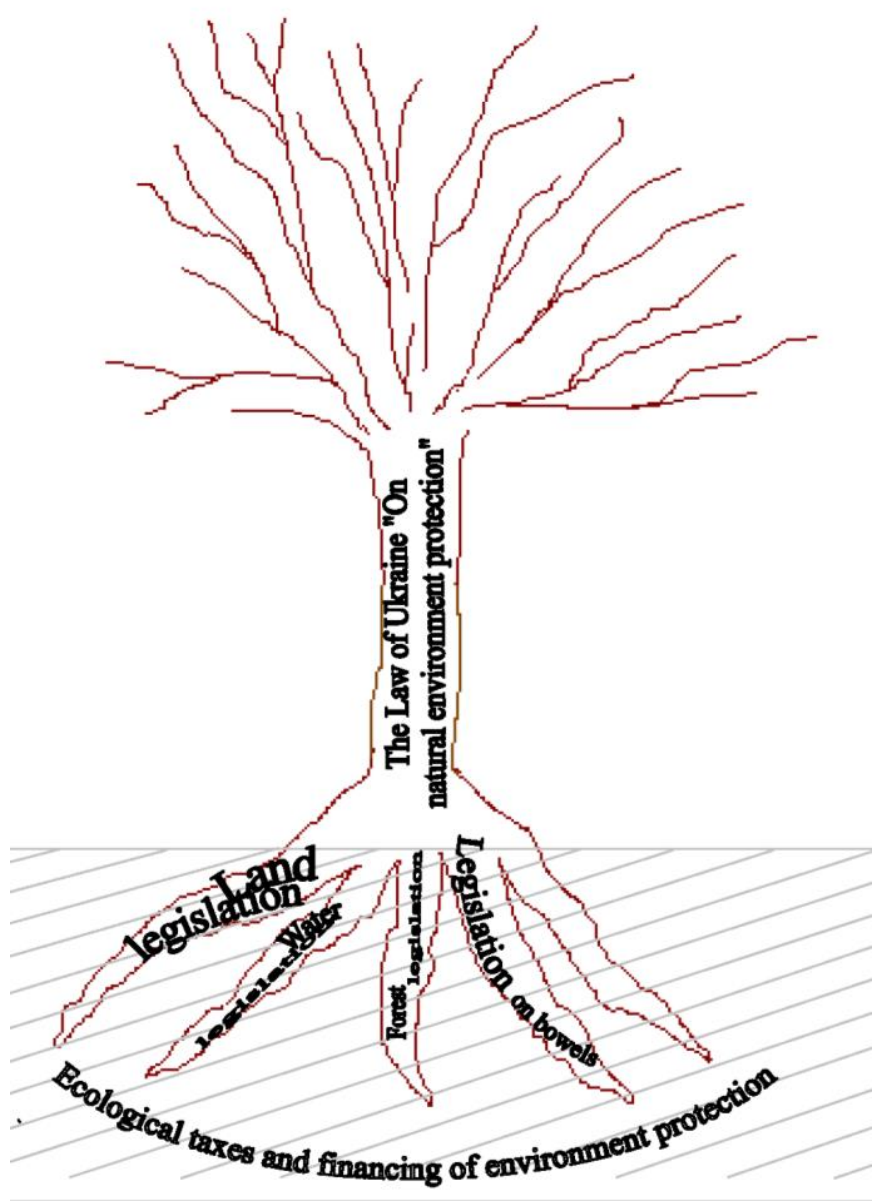

Fig. 2. The "Ecological Tree" in Case of Absence of the Institute
of Ecological Safety

Therefore, the first stage of conception of the "ecological tree" which today looks somewhat naive has been realized. Nowadays it is necessary to provide ecologization of other branches of legislation, to adopt a law on ecological education $^{21}$, worked out with author's input back in 1992, to

${ }^{21}$ Костицький В.В. Програмне забезпечення еколого-правової підготовки інженерних кадрів // Рад. право. - 1989. - № 10; Костицький В.В. Організація безперервного екологічного виховання / Зб.: Географічні системи природокористування Волині. Тези 
initiate in its accordance an obligatory ecological qualifying minimum for all government officials and enterprise workers, i.e. nature users. Unfortunately, today in questions of ecologization of legislation we stand farther than twelve years ago when even without legislative requirement all regulatory legal acts were examined by the Ministry of Protection of Natural Environment of Ukraine (now the Law of Ukraine "On Ecological Examination" is in effect). However, we became witnesses of both ecological nihilizm in the law-making sphere and revisionism which showed itself in attempts of liberalization of requirements to ecological safety and liberal changes in the Law of Ukraine "On Protection of Natural Environment".

Ukrainian legal idea still has to find optimal principles of cooperation and differentiation of branches of law. Obviously, nowadays we should display patience and consideration, remembering that one or few legislative acts do not provide coordination and efficiency of public relations. A number of laws seem necessary, something similar to the "critical mass" in physics to make all the legal system "begin to work". Even within the limits of one branch of law it is difficult to obtain necessary effect without corresponding innovations in other branches of law. For instance, insufficient effectiveness of the Law of Ukraine "On Protection of Natural Environment" is largely stipulated by delay of alterations to the Code on Administrative Offences of Ukraine and absence of law on state control in the sphere of environmental protection.

Today we face the necessity of codification of ecological law and adoption of the Ecological Code of Ukraine which would take into account recent achievements not only of the law science but also of law-making and lawenforcement practice.

Nowadays ecological law in Ukraine has been finally formed as an independent branch of law. It represents generalized interest, legalized public need in maintenance, rational use and recreation of natural resources, protection of landscapes, ecosystems and environment on the whole as conditions of further existence of the human civilization ${ }^{22}$.

\section{Principles of Ecological Law}

Considering the legislative system as a holistic phenomenon, the author notes that the principles of legislation, along with the subject and method of legal regulation, are the criteria for delimiting the branches of legislation. The

\footnotetext{
доповідей. - Луцьк. - 14-16 лютого 1994 р. та ін. Kostytsky V.V. Software for environmental legal training of engineering personnel // Rad. right. - 1989 - № 10; Kostitsky V.V. Organization of continuous ecological education / Coll.: Geographic systems of nature management in Volyn. Abstracts. - Lutsk. - February 14-16, 1994 and others.

${ }^{22}$ Костицький В.В. Лісове право України. - К., 1999. - С. 10. Kosthtsky V.V. Forest Law of Ukraine. - K., 1999. - P. 10.
} 
principles of legislation are peremptory legal norms enshrined in the Constitution and laws of Ukraine, due to the objective needs of the legal regulation of public relations.

The principles of environmental (ecological) legislation express the main objective laws of the mechanism of interaction between the individual, society and the natural environment of a person and determine the essence of environmental legislation.

The principles of environmental legislation are an expression of public environmental interests, and operate within all sub-sectors and institutions of environmental legislation, are enshrined in the relevant provisions of the laws, act as the most concentrated supremacy of the principles of environmental law, and interact with the principles of environmental policy.

Defining the system of principles of environmental legislation of Ukraine as an integrated unity of environmental and legal guiding ideas that have a generally binding character, relative independence, and the ability to interact with other elements of the system, the author sees this as the source of the creation of an environmental legal order.

The work focuses on the fact that in modern science, in theoretical and methodological terms, there is no consistent delimitation of the principles of environmental legislation on industry, sub-industry and institutional, there is excessive declarativeness in their formulation. As a result, the potential of using sub-industry and institutional principles of environmental legislation to implement the constitutional principles of environmental protection is underestimated.

The author joins the opinions expressed in the legal literature that the principles of environmental legislation of a regulatory and protective nature are not equally enshrined in the legislation, and therefore an important task of theoretical science is the requirement for the correct formulation of these principles, taking into account their integrative nature and importance for structuring environmental legislation.

Principles of ecological law consist in fundamental ideas, basic principles, peculiarities, properties which are typical of all legal norms of ecological law, according to which regulation of ecological relations is carried out. From our point of view, the above-mentioned list of features has to be definitely complemented by such characteristics as requirements. Primarily, principles are nothing else but requirements in accordance with which certain legislative norms must be reflected in corresponding acts. Principles are the basis of construction and functioning of law, de facto they are obligatory in the part of inhibition for all the subjects of ecological relations without exception; their current state de jure determines the level of legal consciousness and culture of the society, in the part of the subject of research - a level of its ecological 
behaviour. Principles of ecological law are characterized by the process of permanent development the dynamics of which is determined by transformation of tasks in the sphere of exploitation of natural resources, environmental protection and providing ecological safety in conditions of increased changeability of the environment, the system of ecological relations, largely predefined by the change of ecological requirements on national and international levels.

Principles of ecological law apart from its object and methods of legal regulation of ecological relations are criteria which allow to distinguish ecological law from other branches of law, to determine the nature of ecological law as a complex branch of law.

In scientific works structuring principles of ecological law is carried out by their systematization into basic groups and also by singling out basic principles inside each of such groups.

First of all, ecological law is based on the system of general (which determine the essence of law on the whole - principles of social justice and social freedom, equality (equal protection of the law), unity of legal rights and duties, lawfulness, inevitability, etc.) and special (branch-related - which concern and operate within the limits of one branch) principles. At the same time differences in approaches of a number of scientists take place in the part of systematization of basic principles of ecological law.

$\mathrm{Yu}$. Shemshuchenko, in particular, distinguishes the following basic principles of ecological $\operatorname{law}^{23}$ : consistency and complexity in regulation of ecological relations; order of precedence of citizens' rights to the environment safe for life and health (Article 50 of the Constitution of Ukraine, Article 9 of the Law of Ukraine "On Protection of Natural Environment"); prevention of ecological harm (Article 3 of the Law of Ukraine "On Protection of Natural Environment"); combination of rights and duties, stimulation and liability in the sphere of action of ecological law (articles 55 and 66 of the Constitution of Ukraine, Article 3 of the Law of Ukraine "On Protection of Natural Environment").

Meanwhile, A. Hetman and A. Shulha ${ }^{24}$ distinguish the following principles of ecological law: principle of legal support of achieving

${ }^{23}$ Екологічне право України. Академічний курс: Підручник. - Друге видання / За заг. ред. Ю.С. Шемшученка. - К.: ТОВ “Видавництво "Юридична думка", 2008. - 720 с. Environmental Law of Ukraine. Academic course: Textbook. - Second edition / For the head. ed. Yu.S. Shemshenko. - K. : LLC "Legal Thought Publishing House, 2008. - 720 p.

${ }^{24}$ Гетьман А.П., Шульга М.В. Екологічне право України: Підручник. - Харків.: Право, 2005. - режим доступу до інформації: http://ebk.net.ua Getman A.P., Shulga M.V. Environmental Law of Ukraine: Textbook. - Kharkiv: Law, 2005. - mode of access to information: http://ebk.net.ua 
harmonious cooperation of society and nature (as the main principle); principle of legal support of ecological safety; principle of legal record of belonging of natural resources to certain legal subjects and their use with the aim of satisfaction of ecological, property and other interests within the limits of legislation; principle of legal support of rational and effective use of natural resources; principle of legal support of proper use of natural objects; principle of legal support of stimulating proprietors and users of natural objects to properly use natural resources, recreate and protect them; principle of legal support of stable (long-lasting) use of natural resources; principle of legal support of a complex approach to use and recreation of natural resources and to environmental protection.

While classifying principles of ecological law it seems reasonable to follow the approach formulated by A. Hetman and A. Shulha, according to which "classification of ecological and legal principles... has to be based on ecological legislation or derive from its content. Without taking this factor into account proclaimed principles become declarations of the state or the author of these principles" 25 .

Considering the above-mentioned ideas, it is logical to appeal to principles of protection of natural environment, proclaimed in Article 3 of the Law of Ukraine "On Protection of Natural Environment".

Principles reflected in the given law directly concern ecological law because this is the latter by which ecological activity as a specific sphere of public relations is regulated.

However, since the Law of Ukraine "On Protection of Natural Environment" was adopted many years have passed and today we can talk about a new system of principles of ecological law to which belong the following: priority of requirements of ecological safety, obligatoriness of inhibition of ecological standards, norms and limits of use of natural resources in the activity of public and local self-government bodies, and also in the process of realizing economic, administrative, humanitarian, social and other activity; duty of the state to guarantee the environment ecologically safe for life and health of people, to provide favourable ecological conditions of person's work and rest; realization of the principle of prudence in planning or introduction of any measures which presupposes warning or minimization of risk or danger of negative influence on the environment; realization of the principle "a polluter pays" in legislative activity and law enforcement of the

\footnotetext{
${ }^{25}$ Гетьман А.П., Шульга М.В. Екологічне право України: Підручник. - Харків.: Право, 2005. - режим доступу до інформації: http://ebk.net.ua Getman A.P., Shulga M.V. Environmental Law of Ukraine: Textbook. - Kharkiv: Law, 2005. - mode of access to information: http://ebk.net.ua
} 
state, in other words the introduction of paid access for industrial and economic activity which leads to environmental pollution and worsening the quality of natural resources, introduction of ecological taxes; solution to problems of environmental protection on the basis of wide intergovernmental collaboration; subsidiarity of ecological policy of the state, in other words application of international norms and rules in ecological policy of the state if they appear to be more effective than national ones; ecological patriotism, realization of economic, political, humanitarian, social and other activity taking into account ecological interests of Ukraine, priority for society of life supporting (social, recreational, protective) functions of biosphere concerning direct (raw material) use of natural resources, use of national standards, if their requirements are more effective for achievement of tasks of environmental protection than international ones; principle of integration in realization of ecological measures of the state; basinal approach to management in the sphere of environmental protection, guard and use of natural resources; citizens' right to participate in realization of public ecological policy; compensation of harm and losses caused by violation of legislation on environmental protection.

Application of any principle of environmental protection cannot lead to violation of the other principle or person's right to ecological safety and environmental protection.

\section{CONCLUSIONS}

Moral and ecological ethics are at the heart of making any environmentally sound decisions. The question of salvation of modern civilization lies in the field of environmental ethics, including through the adoption and implementation of the Earth's Ecological Constitution. The international legal environmental imperative (the moral imperative of good), as an ideal to which we would all strive together to preserve the Earth for our children and grandchildren, must obviously be the content of the Earth's Ecological Constitution, which should precede the harmonization of the constitutional consolidation of human rights. living in a favorable environment and other environmental rights as a condition and obligation of the state to ensure sustainable development and carry out an ecological function in accordance with the requirements of international and national environmental law.

The components of the development of law should be not only the further progress of environmental science, the enhancement of the ecological and legal culture, the improvement of the eco-legal education system, but, above all, the improvement of the legislation, taking into account the normative force of the law, its general binding nature. We now face the need to codify 
environmental legislation and adopt the Environmental Code of Ukraine, which would take into account the latest developments in both legal science and law-making and law enforcement. Such a need is also objectively attributed to the fact that it is now generally accepted to distinguish environmental law as a complex branch of law, which brings together a relatively independent set of rules of law governing certain spheres of social relations, united in separate branches, sub-branches and institutions of law.

The codification of environmental law must be carried out at the level of creation of new rules of law. After all, a legal rule - a specific rule of conduct, established or sanctioned and enforced by the state - is the least structural component of the environmental law system. The rule of law can be compared to a molecule of a substance that is known to be the smallest constituent of a substance that retains the properties of that substance. A water molecule is water, and two hydrogen or oxygen atoms have different properties compared to water. The rule of law is the smallest piece of law that holds the properties and features of law. The most striking feature of this law is manifested in environmental law, which combines legal rules aimed at preserving the environment in which a person lives.

Therefore, environmental law is a complex area of law that regulates legal relations in the field of nature protection, rational use of natural resources and ensuring environmental safety, that is, relations related to environmental protection in general, protection and use of natural resources and protection of life and health. human beings due to the negative impact of human activity on the environment in order to ensure a balanced sustainable development for the benefit of present and future generations of people.

The criteria for the "identification" of environmental law in the legal system are the public inquiry caused by the imminent global ecological crisis, as well as the identification of the subject, methods of regulation of social relations and environmental principles.

As a result, the tendency for the rapid development of both international environmental law and national environmental legislation was established, accompanied by an unprecedented phenomenon - the mutual "flow" of progressive environmental ideas between national and international environmental law.

The highest achievement here should be considered the constitutional fixing in a number of countries of the natural human right to life and to the environment, other environmental rights that flow from it (Constitution of the Republic of Tataria, Article 35 of the Charter of Fundamental Rights and Freedoms of the Czech Republic, the Constitution of Estonia, Macedonia, Moldova, Slovenia, Russian Federation). 
The human right to a clean environment in the constitutions of modern states is considered to be the legal basis for the legal consolidation of the ecological function of the state. In this way, preserving the environment for present and future generations in modern law theory and constitutional practice is seen as a shared responsibility of the state, civil society and man. This approach can be defined as an international legal environmental imperative, which is accepted in almost every country in the world.

Further development of the Institute for Environmental Rights and Freedoms should take into account the emerging trends of mutual" transfusion "of scientific ideas and provisions between national legislation and international environmental law, especially the processes of globalization. It has become generally accepted the constitutional consolidation of environmental responsibilities of citizens, which corresponds to the environmental right to a life-friendly and clean environment. We note here the experience of the Czech Republic, whose constitution shared the obligation to perform an ecological function between the state and civil society.

Such provisions are enshrined directly or indirectly by the constitutions of Austria, Macedonia, Moldova, Portugal, Slovenia, Hungary, Ukraine. The constitutions of the Republic of Belarus, Macedonia, Moldova, the Russian Federation, Slovenia and Uzbekistan proclaim the duty of everyone to protect the natural environment.

A number of constitutions of modern states have implemented international principles that have become the property of modern science and international practice. This applies not only to the human right to environmental information, but also to the principle of sustainable (stable) development as fundamental to ensuring environmental safety and the realization of the human right to an environment conducive to life and health. Thus, in order to realize the human right to live in an environment of ecological balance, the Portuguese Constitution is obliged to develop the rational use of natural resources, preserving their capacity for renewal and environmental sustainability, to promote balanced socio-economic development, to develop a national energy policy aimed at the conservation and conservation of natural resources equilibrium.

\section{SUMMARY}

Globalization implies the creation of a new environmental ethic in the global civil society of the post-industrial era. The ethics of global civil society will be guided by the priority of human interests, the desire to preserve and pass on the Earth and modern civilization to the next generations. Man in the 21 st century, like modern society as a whole, continues to be as integral to nature as it was centuries and millennia ago. Global civil society is 
accompanied by the transformation of man into a citizen of the world and the affirmation of the dominant environmental rights and freedoms of the individual as a condition for the development of modern society.

\section{REFERENCES}

1. Alekseev S.S. Right. Alphabet. Theory. Philosophy. Experience in complex research. - M.: Charter, 1999.

2. Andreytsev V.I. Environmental Law: Lecture Course in Schemes. The common part. - K : Venturi, 1996.

3. Ecological Constitution of the Earth. Methodological basis / [V.V. Kostytsky et al. in a row. Acad. NAS of Ukraine, Doctor of Economics. of sciences, prof. Tunisia]. - Lviv: RVV NLTU of Ukraine, 2011. P. 370-381.

4. Environmental Law of Ukraine. Academic course: Textbook. - Second edition / For the head. ed. Yu.S. Shemshenko. - K : LLC "Legal Thought Publishing House, 2008. - 720 p.

5. Hegel GVF Philosophy of Law. - M.: "Thought", 1990.

6. Hetman A.P., Shulga M.V. Environmental Law of Ukraine: Textbook. - Kharkiv: Law, 2005. - mode of access to information: http://ebk.net.ua.

7. Kolbasov O.S. Ecology: politics - law. Legal protection of nature in the USSR. - M.: "Science", 1976.

8. Kostytsky V.V. Ecological law of Ukraine: some problems of theory and codification // Law of Ukraine. - 1998. - № 1. - P. 67-72.

9. Kostytsky V.V. Ecology of Transition: Law, State, Economy (Economic and Legal Mechanism of Environmental Protection in Ukraine) / V.V. Kostytskyi; Institute for Legislative Predictions and Legal Expertise. K.: USSB SME Eusmeu, 2003. - 772 p.

10. Kostytsky V.V. Forest Law of Ukraine. - K., 1999.

11. Kostytsky V.V. Methodological problems of codification of environmental legislation / V. Kostytsky // Small and medium-sized business (Law, State, Economics). - 2011. - № 3-4. - P. 3-6.

12. Kostytsky V.V., International legal ethical imperative as the basis of theoretical and methodological support for the development of environmental law / V. Kostytskyi // Law of Ukraine. - 2011. - № 2. - P. 20-33.

13. Kostytsky V. Problems of development of environmental law of Ukraine / Coll. of theses: Environmental Management in Ukraine: A Comparative Analysis of Ukrainian and Western European Approaches. May 21-31, 1991 - Geneva. - 1991.

14. Kostytsky V.V. Software for environmental legal training of engineering personnel // Rad. right. - 1989 - № 10. 
15. Protasov V.F., Molchanov A.V. Dictionary of environmental terms and concepts. - M., 1997. - P. 101.

16. Rabinovich PM Human rights and their legal support (foundations of the general theory of law and state). - K., 1992. - P. 7.

17. Shemshuchenko Y.S. Legal problems of ecology. - K: Sciences. Thought, 1989.

Information about the author: Kostytsky V.,

Doctor of Law (DrSc.), Professor, President of the International Environmental Academy ORCID: 0000-0003-1692-9810 